\title{
PENGEMBANGAN SUMBER DAYA MANUSIA MELALUI PENINGKATAN PROFESIONALISME GURU PKN YANG BERWAWASAN TEKNOLOGI INFORMASI
}

\author{
Arie Supriati \\ Jurusan PPKn Fakultas Ilmu Sosial \\ Universitas Negeri Manado \\ ariesupriati@unima.ac.id
}

\begin{abstract}
ABSTRAK
Jabatan Guru merupakan suatu jabatan professional yang menuntut kemampuan spesialis sebagai Guru. Dengan kata lain Guru harus menguasai pengetahuan akademik, kemahiran professional dan teknologi yang relevan dengan bidang tugasnya sebagai pendidik. Pengenmbangan profesionalisme Guru secara nasional diharapkan dapat menghasilkan sumber daya manusia (SDM) yang berkualitas sehingga dapat bersaing di era teknologi informasi dan globalisasi. Dengan SDM yang berwawasan teknologi informasi diharapkan dapat mengkaji, menganalisis dan mangatasi masalah-masalah pendidikan yang ada sehingga diharapkan pada akhirnya mutu pendidikan di Indonesia dapt meningkat sesuai degan harapan bangsa Indonesia. Penelitian ini mengkaji tentang Pengembangan Sumber Daya Manusia Melalui. Peningkatan Profesionalisme Guru PKn Yang Berwawasan Teknologi Informasi dengan obyek penelitian di SMPN 1 Kalawat. Tujuan penelitian ini adalah untuk memperoleh data dari kesimpulan empiris tentang Pengembangan sumber daya manusia melalui peningkatan profesionalisme guru yang berwawasan teknologi informasi pada SMP N1 Kalawat. Metode yang digunakan adalah metode deskriptif kualitatif dengan teknik pengumpulan data melalui observasi, wawancara dan data dokumentasi sekolah. Hasil dari penelitian ini menunjukkan bahwa Peningkatan Profesionalisme Guru PKn Yang Berwawasan Teknologi Informasi di SMN 1 Kalawat cukup optimal dengan menekankan pada pengetahuan, keterampilan dan sikap percaya diri
\end{abstract}

\section{Kata Kunci: SDM, Profesionalisme Guru, Teknologi Informasi}

\section{PENDAHULUAN}

Pendidikan adalah sarana utama bagi suatu Negara dalam meningkatkan perkembangan dunia. Oleh karena itu, pendidikan patut memperoleh perhatian utama dalam perbaikan kualitas manusia. Kalau tidak, suatu bangsa akan ketinggalan dengan bangsa lainnya di dunia, lebih-lebih lagi dalam percaturan dunia yang menggunakan teknologi canggih dan serba tanpa batas (borderless).

Melalui pendidikaan kewarganegaraan, setiap warga Negara republik Indonesia diharapkan mampu memahami, menganalisa dan menjawab masalah-masalah yang dihadapi masyarakat, bangsa dan negaranya secara konsisten dan berkesinambungan dalam mencapai cita-cita dan tujuan nasional sebagaimana yang diamanatkan dalam pembukaan UUD 1945. Karena itu sebagai generasi penerus bangsa, setiap warga Negara Indonesia haruslah menyadari arti pentingnya Pancasila sebagai dasar dan ideologi Negara, persatuan dan kesatuan bangsa, norma hukum dan peraturan dalam berbangsa dan bernegara, pengakuan dan penegakan HAM, konstitusi Negara yang mengatur hubungan pemerintah dengan rakyat dan kekuasaan dalam Negara.

Pendidikan harus mampu mengembangkan manusia Indonesia yang bermutu, yaitu yang mampu menunjang ketahanan bangsa dalam era global. SDM yang bermutu paling tidak memiliki kompetensi mendasar antara lain, mampu menguasai keahlian bidang iptek; mampu bekerja secara profesional serta mampu menghasilkan karya yang bermutu (Suryadi). Indonesia telah melakukan perbaikan kualitas 
pendidikan dengan menempatkan guru sebagai prioritas utamanya, dengan cara mengembangkan Sumber Daya Manusia Melalui Peningkatan Profesionalisme Guru PKn Yang Berwawasan Teknologi Informasi Sebagai salah unsur dalam sistem pendidikan nasional, perbaikan kualitas dan nasib guru diharapkan dapat meningkatkan kualitas pendidikan pada umumnya, karena guru merupakan ujung tombak dalam proses pendidikan.

\section{KAJIAN TEORI}

\section{Profesionalisme Guru}

Dalam UU RI NO. 14 tahun 2005 tentang guru dan dosen mendefinisikan bahwa "professional adalah pekerjaan atau kegiatan yang dilakukan oleh seseorang dan menjadi sumber penghasilan kehidupan yang memerlukan keahlian, kemahiran, atau kecakapan yang memenuhi standar mutu atau norma tertentu serta memerlukan pendidikan profesi". Professional membawa pemikiran kita pada pekerjaan yang menuntut keahlian tertentu. Menurut Danim, Sudarwan, makna professional merujuk pada dua hal. Pertama, orang yang menyandang suatu profesi. Orang yang professional biasanya melakukan pekerjaan sesuai dengan keahliannya dan mengabdikan diri pada pengguna jasa dengan disertai rasa tanggung jawab atas kemampuan profesionalnya itu. Kedua, kinerja atau performance seseorang dalam melakukan pekerjaan yang sesuai dengan profesinya

Profesionalisme merupakan proses peningkatan kualifikasi atau kemampuan para anggota penyandang suatu profesi untuk mencapai kriteria standar ideal dari penampilan atau perbuatan yang diinginkan oleh profesinya itu. Profesionalisasi mengandung makna dua dimensi utama, yaitu peningkatkan status dan peningkatan kemampuan praktis. Aksentasinya dapat dilakukan melalui penelitian, diskusi ilmiah antar rekan seprofesi, penelitian dan pengembangan, membaca karya ilmiah yang terkini dan lain - lain. Kegiatan belajar mandiri, mengikuti pelatihan, studi banding, observasi praktikal dan lain-lain.

Dilihat dari segi fisik yaitu guru harus sehat jasmani dan rohani serta tidak memiliki cacat tubuh yang dapat menghambat tugasnya dan juga menimbulkan ejekan atau rasa kasihan dari siswanya. Dari aspek mantal/kepribadian mencakup berkepribadian/berjiwa Pancasila, mampu menghayati GBHN, mencintai bangsa dan sesama manusia, dan rasa kasih saying kepda anak didik, berbudi pekerti yang luhur, berjiwa kreatif, dapat memanfaatkan rasapendidikan yang ada secara maksimal, mampu menyuburkan sikap demokrasi dan penuh tenggang rasa, amampu mengembangkan kreativitas dan tanggung jawab yang besar akan tugasnya, mampu mengembangkan kecerdasan yang tinggi, bersifat terbuka, peka dan inovatif menunjukkan rasa cinta kepada profesinya, ketaatannya akan disiplin dan memiliki sense of humor. Untuk kriteria keilmiahan/pengetahuan seorang guru harus memahami ilmu yang dapat melandasi pembentukan pribadi, memahami ilmu pendidikan dan keguruan dan mampu menerapkannya dalam tugasnya sebagai pendidik, memahami, menguasai, serta mencintai ilmu pengetahuan yang akan diajarkan, memiliki pengetahuan yang cukup tentang bidang-bidang yang lain, senang sistematis, terutama yang berhubungan dengan bidang studi

\section{Konsep Pengembangan}

Pengembangan adalah setiap usaha untuk memperbaiki pekerjaan yang sekarang maupun yang akan datang, dengan memeberikan informasi, mempengaruhi sikap atau

menambah kecakapan. Dengan kata lain pengembangan adalah setiap kegiatan yang dimaksudkan untuk mengubah perilaku yang terdiri dari pengetahuan, kecakapan

dan sikap (Moekijat).

istilah pengembangan menunjukkan pada suatu kegiatan menghasilkan suatu alat atau cara yang baru, dimana selama kegiatan tersebut terusmenerus dilakukan. Bila setelah mengalami penyempurnaan-penyempurnaan akhirnya alat atau cara tersebut dipandang cukup mantap untuk digunakan seterusnya maka berakhirlah dengan kegiatan pengembangan.

\section{Konsep Sumber Daya Manusia}

Manajemen sumber daya manusia, disingkat MSDM, adalah suatu ilmu atau cara bagaimana mengatur hubungan dan peranan sumber daya (tenaga kerja) yang dimiliki oleh individu secara efisien dan efektif serta dapat 
digunakan secara maksimal sehingga tercapai tujuan (goal) bersama perusahaan, karyawan dan masyarakat menjadi maksimal. MSDM didasari pada suatu konsep bahwa setiap karyawan adalah manusia- bukan mesin - dan bukan semata menjadi sumber daya bisnis (Achmad. S. Rucky).

Faktor manusia merupakan sumber daya sebagai titik sentral berpikir, perencanaan, perekayasa, perancang bangunan dan pelaksana ataupun penyelenggara pembangunan dan atau pelaku pembangunan.

Pendapat lain mengatakan bahwa Sumber Daya diartikan sebagai alat untuk mencapai tujuan atau kemampuan memperoleh keuntungan dari kesempatan-kesempatan tertentu, atau meloloskan diri dari kesukaran sehingga perkataan sumber daya tidak menunjukkan suatu benda, tetapi dapat berperan dalam suatu proses atau operasi yakni suatu fungsi operasional untuk mencapai tujuan tertentu seperti memenuhi kepuasan.

Dengan kata lain sumber daya manusia merupakan suatu abstraksi yang mencerminkan aspirasi manusia dan berhubungan dengan suatu fungsi atau operasi (Simamora)

\section{Pengembangan Profesionalis-me Guru PKn}

Pengembangan profesionalisme guru PKn adalah usaha yang diberikan kepada guru dalam upaya perbaikan dan peningkatan kompetensi yang dijalani, sehingga guru sebagai anggota profesi dapat meningkatkan mutu, kualitas, sikap dan komitmen untuk bekerja berdasarkan standar yang paling ideal dari kode etik.

Misi pendidikan kewarganegaraan adalah untuk membantu siswa memantapkan kepribadiannya, agar secara konsisten mampu mewujudkan nilainilai dasar Pancasila, rasa kebangsaan dan cinta tanah air dalam menguasai menerapkan dan mengembangkan ilmu pengetahuan teknologi dan seni dengan rasa tanggung jawab dan bermoral.

\section{Kompetensi yang diharapkan dari pendidikan kewarganegaraan.}

\section{a. Hakikat pendidikan}

Generasi penerus diharapkan akan mampu mengantisipasi hari depan mereka yang senantiasa berubah dan selalu terkait dengan konteks dinamika budaya,bangsa,Negara,dan hubungan internasional. Pendidikan tinggi tidak dapat mengabaikan realita kehidupan global yang digambarkan sebagai perubahan kehidupan yang penuh dengan paradox dan ketakterdugaan. Karena itu, ppendidikan kewarganegaraan dimaksudkan agar kita memiliki wawasan kesadaran bernegara untuk belanegara dan memiliki pola pikir, pola sikap dan perilaku sebagai pola tindak yang cinta tanah air berdasarkan pancasila. Semua itu diperlukan demi tetap utuh tegaknya Negara Kesatuan Republik Indonesia.

\section{b. Kemampuan warga Negara}

Untuk hidup berguna dan bermakna serta mampu mengantisipasi perkembangan, perubahan masa depannya, suatu Negara sangat memerlukan pembekalan ilmu pengetahuan, teknologi dan seni yang berlandaskan nilai-nilai pancasila, nilai-nilai keagamaan dan nilai-nilai perjuangan bangsa.

\section{c. Menumbuhkan wawasan warga Negara}

Setiap warga Negara Republik Indonesia harus menguasai ilmu pengetahuan, teknologi, dan seni yang merupakan misi atau tanggung jawab pendidikan kewarganegaraan untuk menumbuhkan wawasan wargaa Negara dalam hal persahabatan, pengertian antar bangsa, perdamaian dunia, kesadaran bela Negara, dan sikap serta perilaku yang bersendikan nilai-nilai budaya bangsa, wawasan nusantara dan ketahanan nasional.

\section{d. Dasar pemikiran kewarganegaraan.}

Rakyat Indonesia, melalui Majelis Perwakilan (MPR), Menyatakan bahwa: pendidikan nasioanal ynag berakar ppada kebuayaan bangsa Indonesia di arahkan untuk menigkatkan kecerdasan serta harkat dan martabat bangsa, mewujudkan manusia serta martabat Indonesia yang beriman dab bertakwa kepada Tuhan Yang Maha Esa, berkualitas mandiri, sehingga mampu membangaun Nasional dan bertanggung jawab atas pembangunan bangsa". Jiwa patriotic, rasa cinta tanah air, semangat kebangsaan, kesetiakawanan social, kesadaran pada sejarah bangsas, dan sikap menghargai jassa para pahlawan di kalangan mahasiswa hendak hendak di pupuk melalui pendidikan kewarganegaraan. 


\section{e. Kompetensi yang diharapkan}

Kompetensi diartikan sebagai perangkat tindakan cerdas, penuh rasa tanggung jawab yang harus di miliki oleh seseorang agar ia mampu melaksanakan tugas-tugas dalam bidang pekerjaan tertentu. Melalui pendidikan kewarganegaraan, warganegara kesatuan republik Indonesia diharapkan mampu: "memahami, menganalisis, dan menjawab masalah-masalah yang dihadapi oleh masyarakat, bangsa, negaranya secara berkesinambungan dan konsisten dengan citacita dan tujuan nasional seperti yang digariskan dalam pembukaan UUD 1945". (Sumarsono, 2017)

David Kerr mengemukakan bahwa Citizenship or Civics Education is construed broadly to encompass the preparation of young people for their roles and responsibilities as citizens and, in particular, the role of education (through schooling, teaching and learning) in that preparatory process. Pendapat tersebut menjelaskan bahwa pendidikan kewarganegaraan dirumuskan secara luas mencakup proses penyiapan generasi muda untuk mengambil peran dan tanggung jawabnya sebagai warga negara, dan secara khusus, peran pendidikan (termasuk di dalamnya persekolahan, pengajaran, dan belajar) dalam proses penyiapan warga negara tersebut. Untuk konteks di Indonesia, citizenship education oleh beberapa pakar diterjemahkan dengan istilah pendidikan kewarganegaraan (Naiborhu, 2016: 86).

Untuk mewujudkan mata pelajaran Kewarganegaraan sebagai wahana untuk membentuk warga negara yang cerdas, terampil dan berkarakter yang setia kepada bangsa dan negara Indonesia dengan merefleksikan dirinya dalam kebiasaan berfikir dan bertindak sesuai dengan amanat Pancasila dan UUD 1945, maka mata pelajaran pendidikan kewarganegaraan bertujuan untuk memberikan kompetensikompetensi sebagai berikut:

1. Berfikir secara kritis, rasional, dan kreatif dalam menghadapi isu kewarganegaraan.

2. Berpartisipasi secara bermutu dan bertanggungjawab, dan bertindak secara cerdas dalam kegiatan bermasyarakat, berbangsa, dan bernegara.

3. Berkembang secara positif dan demokratis untuk membentuk diri berdasarkan karakter- karakter masyarakat Indonesia agar dapat hidup bersama dengan bangsa-bangsa lainnya.

4. Berinteraksi dengan bangsa-bangsa lain dalam percaturan dunia secara langsung atau tidak langsung dengan memanfaatkan teknologi informasi dan komunikasi.

Sedangkan pengertian pendidikan kewarganegaraan yaitu: Menurut Zamroni Pendidikan kewarganegaraan adalah pendidikan demokrasi untuk bertujuan mempersiapkan warga masyarakat berpikir kritis dan bertindak demokratis, melalui aktivitas menanamkan kesadaran kepada generasi baru tentang kesadaran bahwa demokrasi adalah bentuk kehidupan masyarakat yang paling menjamin hak-hak warga masyarakat. Menurut Azra pendidikan kewarganegaraan adalah pendidikan yang cakupannya lebih luas dari pendidikan demokrasi dan penddikan HAM karena mencakup kajian dan pembahasan tentang banyak hal, seperti: pemerintahan, konstitusi,lembaga-lembaga demokrasi, rule of law, hak dan kewajiban warga Negara, proses demokrasi, partisipasi aktif dan keterlibatan warga Negara dalam masyarakat madani, pengetahuan tentang lembaga-lembaga dan system yang terdapat dalam pemerintahan, politik publik dan system hukum, pengetahuan tentang HAM, kewarganegaraan aktif.

\section{METODE}

Penelitian ini didisain menggunakan penelitian deskriptif kualitatif sebagaimana pendapat Merriam (Creswell, 2010:259) serta akan lebih berinteraksi secara fisik dengan orang, lokasi, atau institusi untuk mengamati atau mencatat perilaku yang berada pada latar penelitian. Penelitian ini menempatkan peneliti sebagai instrumen kunci pengambilan sampel sumber data dilakukan secara proporsional dan snowbal. Sumber data dalam penelitian ini adalah siswa Kelas 2 dan guru pendidikan kewargaan negara di SMPN 1 Kalawat. Waktu pengambilan data dilakukan pada bulan Juni sampai Agustus 2018 dengan menggunakan pengumpulan data dengan teknik observasi, terhadap proses pendidikan kewarganegaraan sebagai penguatan karakter di SMPN 1 Kalawat. Informan dipilih oleh peneliti yang dianggap mampu untuk menggambarkan pengalaman- 
pengalaman mereka, tentang Pengembangan Sumber Daya Manusia Melalui Peningkatan Profesionalisme Guru PKn Yang Berwawasan Teknologi Informasi Prosedur pengumpulan data melalui wawancara mendalam dan bertahap, observasi, catatan dan rekaman hasil pembicaraan informan dengan peneliti serta mengumpulkan data dokumentasi. Sedangkan analisis data bersifat induktif/kualitatif dimana peneliti melakukan analisis terhadap temuan penelitian. Teknik analisis data ini dilakukan dengan tiga alur kegiatan, yaitu reduksi data, penyajian data, dan penarikan kesimpulan Peneliti melakukan analisis data secara kualitatif dan sesuai hasil wawancara dan observasi kemudian melakukan menyajikan data secara deskriptif.

\section{PEMBAHASAN HASIL PENELITIAN}

Sebagai lembaga pendidikan, SMPN 1 Kalawat tanggap dengan perkembangan teknologi. Dengan dukungan SDM yang dimiliki oleh para guru di sekolah siap untuk berkompetisi dengan sekolah lain dalam pelayanan informasi publik. Teknologi Informasi Web khususnya, menjadi sarana bagi SMPN 1 Kalawat untuk memberi pelayanan informasi secara cepat, jelas, dan akuntabel. Dari layanan ini pula, sekolah siap menerima saran dari semua pihak yang akhirnya dapat menjawab Kebutuhan masyarakat.

visi sekolah yakni menjadikan sekolah yang beriman dan bertaqwa, berkarakter, berkualitas di segala bidang, berbudaya dan berwawasan lingkungan serta mengembangkan teknologi sehingga dapat menghasilkan tamatan yang berkualitas. Lima misi sekolah yang kesemuanya bertujuan membentuk karakter siswa yang unggul dalam semua bidang, meliputi: "Pertama membekali siswa dengan ilmu pengetahuan dan keterampilan teknologi yang profesional dan mandiri, Kedua melaksanakan kegiatan kepramukaan dalam penanaman karakter yang baik bagi peserta didik., Ketiga melaksanakan kegiatan belajar mengajar secara efektif, inovatif dan kreatif sehingga dapat meningkatkan mutu pendidikan.

"Keempat menerapkan pendidikan lingkungan hidup terintegrasi dalam proses pembelajaran, Kelima menerapkan kultur sekolah berwawasan pelestarian dan perlindungan lingkungan hidup," Sedangkan Moto SMPN 1 Kalawat adalah : Disiplin, Jujur dan Kerja Keras.

SMPN 1 Kalawat menerapkan penilaian kinerja guru. Penilaian kinerja guru ini sangat penting guna meningkatkan kualitas hasil belajar siswa. SMPN 1 Kalawat memiliki 456 siswa dan 31 orang guru tetap serta 7 orang guru tenaga honorer, yang mengajar pada Kelas VI; VII dan VIII.. Memiliki Prestasi Nasional seperti penghargaan sebagai sekolah Adiwiyata Nasioanal, Pemenang Lomba Bridge dan Tinju Tingkat Nasional.

Program sekolah disusun secara teratur dalam rencana pendidikan sekolah. Seluruh komponen berupaya untuk memberikan rasa nyaman, penuh kebersamaan serta menjunjung tinggi nilai-nilai luhur bangsa, seperti tanggung jawab, disiplin dan tetap ramah kepada siapapun. Pengembangan Sumber Daya Manusia Melalui Peningkatan Profesionalisme Guru PKn Yang Berwawasan Teknologi Informasi telah dilaksanakan pada SMPN 1 Kalawat. Dengan demikian maka mutu pendidikan di SMPN 1 Kalawat dapat terwujud dengan baik.

Berdasarkan hasil penelitian yang telah dilakukan, diperoleh data secara empiris bahwa profesionalisme Guru SMPN 1Kalawat Minahasa Utara. Nampak dari beberapa aspek yaitu peningkatan SDM Guru PKn dalam penguasaaan secara mendalam bahan/mata pelajaran yang diajarkannya, serta cara mengajarkannya kepada siswa, dengan terampil menggunakan metode elekronik berupa LCD.

Dalam jangka panjang, agenda utama upaya meningkatkan sumber daya manusia tenaga kependidikan ialah dengan memperkuat sistem teknologi informasi dengan cara melatih tenaga kependidikan memiliki keterampilan dan keahlian.

Keahlian baru itu adalah modal manusia (human investmen), dan memerlukan perubahan dalam sistem pembelajarannya. Menurut, Hani Handoko, di abad ke-21 perolehan keahlian itu memerlukan perubahan dalam sistem pembelajaran karena alasan: (1) keahlian yang diperlukan untuk mencapai keberhasilan akan semakin tinggi dan berubah sangat cepat, (2) Keahlian yang diperlukan sangat tergantung pada teknlogi dan inovasi baru, maka banyak dari keahlian itu harus dikembangkan dan dilatih 
melalui pelatihan dalam pekerjaan, dan (3) kebutuhan akan keahlian itu didasarkan pada keahlian individu. Ini semua dilakukan agar membentuk suatu sinergi yang erat untuk percepatan indeks pembangunan manusia yang dengan sendirinya meningkatkan daya saing sumber daya manusia Indonesia di kancah global,

Untuk menjawab tantangan ini dibutuhkan tenaga pendidik yang terampil, berkompetensi handal, mengikuti perkembangan teknologi dan berjiwa kreatif dan inovatif.

ketika semua persiapan dan strategi sudah diterapkan maka tidak perlu khawatir akan serbuan tenaga kerja asing yang akan bekerja disini, oleh karena sumber daya manusia Indonesia khususnya para pendidik dan lulusan SMPN 1 Kalawat siap dengan bekal kompetensi yang handal. Bahkan apabila para pendidik dan lulusan SMPN 1 Kalawat sudah menguasai teknologi, kompetensi tersebut akan dapat mudah mengubah dunia dan menjadi tuan rumah dinegerinya sendiri. biarkan sekolah -sekolah swasta juga dapat mengelola untuk bersaing dalam memajukan pendidikan di Indonesia.

Untuk mewujudkan hal itu, perlu pendekatan yang harus sekaligus dilakukan, antara lain: (1) menetapkan kebijakan tentang pentingnya mutu dalam pendidikan dan (2) kemudian meningkatkan Profesionalisme Guru PKn Yang Berwawasan Teknologi Informasi. Dengan demikian maka peningkatan kualitas pendidikan akan lebih cepat terwujud.

\section{KESIMPULAN}

Berdasarkan dari uraian diatas, dapat di simpulkan bahwa ada peningkatan Profesionalisme Guru PKn Yang Berwawasan Teknologi Informasi pada proses pembelajaran di SMPN 1 Kalawat, Kabupaten Minahasa Utara. Sulawesi Utara. Sumber daya manusia Guru ditingkatkan melalui wawasan teknologi Informasi yang handal sebagai bekal kompetensi yang handal.

Dengan misi sekolah yang kesemuanya bertujuan membentuk karakter siswa yang unggul dalam semua bidang. Pengembangan Profesionalisme guru dengan meningkatkan Sumber Daya Manusia para pendidik di bidang PPKn telah memberi ruang kepada pihak pemerintah dan sekolah terutama masyarakat untuk berperan secara optimal dan bersinergi dalam meningkatkan mutu pendidikan, karena materi PPKn yang harus dicakup adalah yang bertujuan mendidik warganegara yang cerdas, partisipatif dan bertanggungjawab. Untuk itu diperlukan kompetensi yang berkait dengan pengetahuan (knowledge), nilai dan sikap (values/ disposition) dan ketrampilan (skills). Pada akhirnya akan lahir warganegara yang cerdas secara social, spiritual dan intelektual. Diantara materi itu ialah human rights, citizenship, civil society, market economy dan lain-lain.

Melalui Pengembangan Sumber Daya Manusia, Peningkatan Profesionalisme Guru PKn Yang Berwawasan Teknologi Informasi para guru dapat terpantau secara lebih baik..Hal ini tentunya akan meningkatkan profesionalisme guru.

\section{DAFTAR PUSTAKA}

Ace Suryadi, 2012 Pendidikan, Investasi SDM dan Pengembangan Pembangunan, Jakarta.Widya Aksara Press

Ahmad Rucky, 2001. Sistem Manajemen Kinerja, Jakarta, Gramedia Pustaka Utama

Creswell, John W. 2005. Resarch Design, Pendekatan Kualitatif, Kuantitatif dan Mixed, Jakarta: Pustaka Pelajar, George R.Terry, Dasar-Dasar Manajemen, Jakarta: PT. Bumi Aksara

Hani Handoko1995, Manajemen Sumber daya Manusia,Yogyakarta, bpfe,

Jurnal Profesi Guru, tentang Pengembangan Profesi Guru Dalam Meningkatkan Kinerja Guru. Tahun

2017. Ayu Dewi Kusuma Putri. Fakultas Ekonomi dan Bisnis. Universitas Pendidikan Indonesia

Maurer, 2009, Rick. "How to Get Commitment Instead of Resistance." Maurer \& Associates. http://www.beyondresistance.com/get_commitment.php.

Moekijat,2010, Manajemen Sumber Daya Manusia, Bandung CV. Mandar Maju 
Nonaka, 1991 The Knowledge-Creating Company. Harvard Business Review (November-December), Rusman, dkk. 2010. Model-model Pembelajaran Mengembangkan Profesionalisme Guru. Jakarta, PT. Raja Grafindo

Ramirez, Alex. "To Blog Or Not To Blog: Understanding And Overcoming The Challenge of Knowledge Sharing." Journal of Knowledge Management Practice 8, no. SI 1 (May 2007).

Sudarwan Danim, Agenda Pembaharuan Sistem Pendidikan, Cet. Ke 2, Yogyakarta: Pustaka Pelajar, 2006

Sumarsono, 2010, Manajemen Keuangan Pemerintah, Jakarta Graha Ilmu

Syaria Syarbain. 2006, Pendidikan Kewarganegaraan. Jakarta, Graha Ilmu 